\title{
Errata et Notes supplémentaires.
}

\section{TOME I.}

Pag. 25 l. 17 lisez 1791 au lieu de 1792.

", 143 u. 53 comparez T. II. p. 30 note.

", 260 l. 9 lisez d'Argence au lieu de de la Régence (V. T. II. p. 44 note).

\section{TOME II.}

". 11 l. 36 s. lisez tou 8 vos clubs au lieu de le $8 \mathrm{clubs}$.

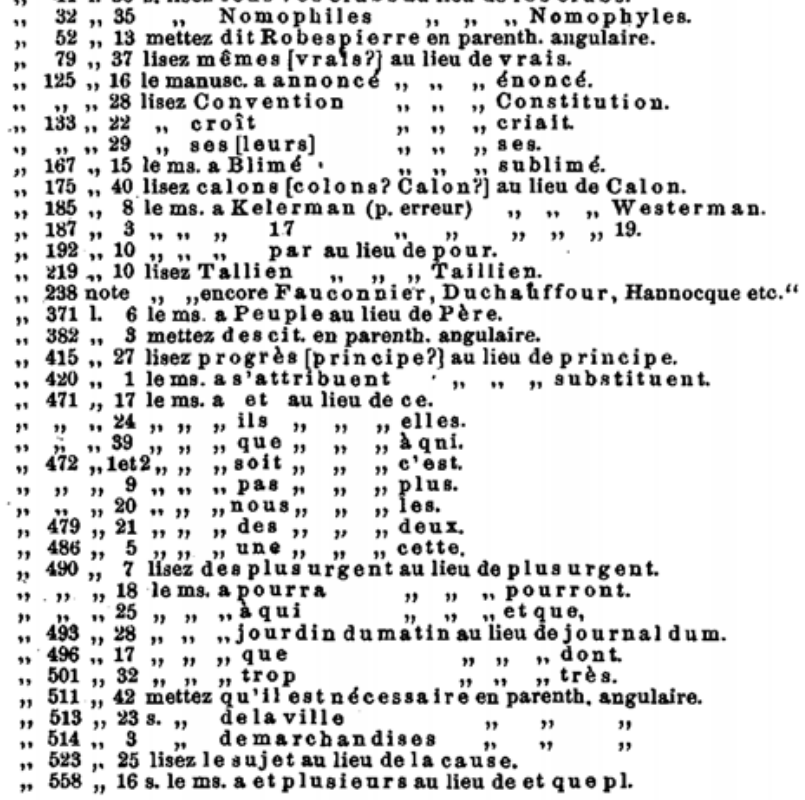

D'ailleurs, on nous dispensers volontiers de la charge d'indiquer toutes les petites négligences que les auteurs ou les copistes des rapports ont commises, et que nous avong cru devoir corriger sans dire mot. (V. T. I. p. IX.) 